\title{
Analysis of Turkish Science Education Curricula's Learning Outcomes According to Science Process Skills
}

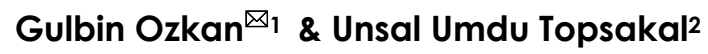 \\ 1,2 Department of Mathematics and Science Education, Yildiz Technical University, Istanbul, Turkey \\ $\bowtie$ gozkan@yildiz.edu.tr
}

\begin{abstract}
This study aims at analyzing the learning outcomes of the 2018 science education curricula in Turkey according to science process skills. Learning outcomes are statements that describe what a learner will know, understand, and/or be able to do after completing a learning process. Learning outcomes were evaluated using document analysis which is a qualitative research method. There were 269 learning outcomes analyzed from the curricula. The science learning outcomes in the curricula which are prepared by the Turkey Ministry of National Education, were examined, starting from fourth-grade to eighth-grade levels. The results show that the least common science process skills are "measuring" and "hypothesizing" dimensions, while the most common are "data interpreting" and "inferring" dimensions. The highest science learning outcomes are at the seventh-grade level, and the least science learning outcomes are at the fifth-grade level. As the grade level increases, it is seen that more learning outcomes represent higher-level skills. The number of basic science process skills of the fourth-grade level learning outcomes is higher than the number of integrated science process skills, and the number of integrated science process skills is high in learning outcomes at all other grade levels.
\end{abstract}

Keywords: science education; curriculum; learning outcome; science process skills

How to Cite: Ozkan, G., \& Umdu Topsakal, U. (2021). Analysis of Turkish Science Education Curricula's Learning Outcomes According to Science Process Skills. Mimbar Sekolah Dasar, 8(3), 295-306. doi:https://doi.org/10.53400/mimbar-sd.v8i3.35746.

INTRODUCTION Constructivist science education aims to create curiosity about the natural world, to observe the natural world, to explain the observation results and to organize their experiences, to develop technical and cognitive competencies that can carry out further studies in the domain of science, and to provide an understanding of the basic concepts about science through experiments (Kim \& Alghamdi, 2019). Achieving these goals is possible only by implementing science teaching based on scientific research.

Science education should focus on raising people with knowledge, skills and actions combined with valuations and qualifications (Tanık \& Saraçoğlu, 2011). While examining the benefits of information, valuations and qualifications through education programs, qualifications and assessments act as a connection and bridge that provides integrity between these information, skills and behaviors (Waltz, Moberly \& Carrigan, 2020). One of the most critical aims of science education is to provide students with knowledge and skills related to the subjects in science programs. This information consists of concepts and theories. It is important to ensure that students understand the notions correctly and can use these concepts in solving the problems they encounter. 
Gulbin Ozkan \& Unsal Umdu Topsakal, Analysis of Turkish Science Education Curricula's...

A curriculum is required to help the learning process be carried out in a planned, programmed and productive way (Zorluoğlu, Bağrıyanık, \& Şahintürk, 2019). The curriculum is equipped with the basis that individual development does not stop in an exact period, it continues constantly (Yüksel, 2007). Therefore, supportive measures are recommended at all ages, taking into account the developmental characteristics of individuals (Zorluoglu \& Kizilaslan, 2019). The innovations and changes made in science curricula in the world in the last thirty years draw attention to whether and how science should be instructed (Osman, 2012).

Science education programs also need to be constantly renewed in the light of changing and developing science. The only way to achieve this goal is to reorganize the science curriculum in accordance with the advances and developments in education, science and technology. The aim of today's modern science education is not for students to memorize scientific information about science, but for them to acquire the necessary scientific attitudes and mental process skills to solve science-related problems that they will encounter throughout their lives, as much as their abilities allow. Thus, instead of learning theoretical knowledge that they will never use, students are expected to think and act scientifically and acquire sciencerelated skills they encounter (Ural \& Gençoğlan, 2019).

The aim of research-based science teaching is to direct students to the science production process and support them to create scientific information as a result of their scientific research. While conducting scientific research, they do not only produce scientific knowledge but also improve their skills of scientific thinking in life and access to information by using scientific processes, and to learn science by living the life (Bağcı-Klıç, 2003). Handayani (2021) stated that elementary science education enables features such as observing and describing natural events to students, asking questions about natural events, using scientific concepts correctly, explaining natural events, predicting events, exhibiting necessary skills in explaining and describing events, conducting experiments that can test natural events. Science process skills help students think rationally, ask meaningful questions, look for answers to these questions, and solve problems they encounter in daily life (Kaymakci \& Can, 2021).). Improving science process skills allows students to solve problems, think critically, make decisions, find answers, and address their concerns. Research skills do not only provide students with some knowledge about science, but also help them think logically, ask reasonable questions and seek answers, and solve problems they face in their daily lives (Ergül et al., 2011).

Science process skills are defined in different ways by researchers. Yildirim, Acarli \& Kasap (2020) define science process skills as the most powerful tool to acquire knowledge about the world and to organize this knowledge. Scientific processes are research processes that form the basis of all scientific fields. It covers the processes that scientists study to explore the inherent world, the cognitive processes included in teaching science, and educational processes in the 
learning environments (Karamustafaoğlu, 2011). Science process skills include the processes applied while doing science and the skills used. Basic science process skills are the most basic skills frequently used in science. Integrated science process skills, on the other hand, are slightly more complex than basic science process skills, and are skills that are built on them (Killiç, Haymana \& Bozyılmaz, 2008).

Appropriate choices of science process skills can be taught. In the first years of elementary school, fundamental skills are noted as a precondition for learning combined skills (Zeidan \& Jayosi, 2015). Science process skills are expected to be included in most of the learning activities. Considering that science process skills are closely related to the child's life (IIma, AlMuhdhar, Rohman \& Saptasari, 2020). According to the literature, it is seen that science process skills enable students to take responsibility for their learning that they are active in the lesson. It is seen that it facilitates participation (Şahin-Pekmez, 2000).

Science process skills are divided into basic and high-level skills (Rubin \& Norman, 1992). Meanwhile, basic and integrated science process skills suggested by Chiappetta and Koballa, (2002) are explained as follows:

Basic science process skills:

Observing: To draw attention to the features of objects and situations using the five senses. It is perception using sense organs.

Measuring: To measure the quantity of a substance or objective quantitatively.

Inferring: To explain a particular object or substance in quantitative terms.

Classifying: To associate or attribute objects and events according to a specific feature.

Predicting: To predict a future event depending on investigations or data expansion.

Communicating: To use words, symbols, or tables to define an object, influence, or situation.

Integrated Science process skills:

Controlling variables: To change and control features related to state events to determine causality.

Hypothesizing: To show a tentative generalization of investigations or inferences that can be used to describe more events comparatively, but are subject to prompt or posttest by one or more experiments.

Experimentation: To test a hypothesis via manipulation and control of independent variables. To record the impacts on a dependent variable and present the results so that others can try 
Gulbin Ozkan \& Unsal Umdu Topsakal, Analysis of Turkish Science Education Curricula's...

to repeat the experiment.

Data Interpreting: To obtain explanations, inferences, or hypotheses from the data table or placed in a figure.

The feature that increases the importance of science process skills is the contribution it provides to students' creativity because science process skills and scientific creativity are complementary to each other (Aktamış \& Ergin, 2007). In this respect, science process skills provide children with the opportunity to examine the events taking place around them from a different perspective (Chan, 2002; Martin, 2012).

One of the goals of the 2018 Turkey science curriculum is to take responsibility for daily life problems, and to use knowledge of the natural sciences in solving these problems. Considering the role of learning outcomes described in the education curricula in the teaching process, the coverage of science process skills in proportion to the levels of the students may affect the students' effective learning. Therefore, it is important to determine to what extent science process skills are represented in the teaching curricula. This study aims at analyzing the learning outcomes of the 2018 science education curricula in Turkey according to science process skills. The sub-problems of the study are as follows:

1. How is the distribution of teaching outcomes in science curricula according to the dimensions of science process skills?

2. How is the distribution of basic and integrated science process skills according to the grade levels of the teaching outcomes in science curricula?

\section{METHOD}

In this study, analysis of science curricula's learning outcomes was made according to science process skills. Learning outcomes were evaluated by using document analysis which is a qualitative research method. Document analysis covers the analysis of written documents which contain information to be investigated. There were 269 learning outcomes analyzed from the curricula. The science learning outcomes in the curricula, which are arranged by the Turkey Ministry of National Education (2018), were examined, starting from fourth-grade to eighth-grade level. These curricula are currently being implemented in Turkey.

In order to make the assessment, analyses were implemented in five steps:

1. Listing science learning outcomes according to grade levels.

2. Determining which scientific process skill is represented by learning outcomes for each grade level. While determining the science process skills, the noun expression of the outcome 
sentence is taken into account. If there is more than one verb phrase in a concluding sentence, higher-level verb expression is taken into account when determining the skill of learning outcomes. The verb expressions used are as follows: for observing; observe, for classifying; compare, relate, for measuring; measure, for inferring; explore, explain, as inferring; recognize, exemplify, grasp, for predicting; guess, communicate; know, recognize, search, specify, for controlling variables; calculate variables, determine variables, determine criteria, for experimentation; design experiments, experiment, prepare models, design, for hypothesizing; estimate (generalization), for data interpreting; discuss, question, produce solutions, offer suggestions, etc... For example; "Student measures the magnitude of the force with a dynamometer." learning outcome in the fifth-grade curriculum is classified as "measuring" from science process skills.

3. If there is more than one verb phrase in a concluding sentence, higher-level verb expression is taken into account when determining the skill of learning outcomes. For example; "The student prepares a model to compare the size of the Sun with the size of the Earth." There are the words "comparison" and "model preparation" in the learning outcome. Since model preparation is a higher-level skill, this learning outcome is evaluated as "experimentation".

4. This analysis was done separately by both researchers and the coefficient of fit was determined as $90 \%$. Different points made by the two researchers were re-evaluated with a third person.

5. As a result of the analysis, the number of learning outcomes represented by each scientific process skill has been turned into frequency tables. Then, basic science process skills and integrated science process skills were calculated according to grade levels.

\section{RESULTS}

In this section, the analysis of science learning outcomes according to the science process skills is done. For this purpose, first of all, the number of learning outcomes according to grade levels is presented in Figure 1. Data analyzed from the curricula-based classification of the science learning outcomes are shown in Figure 2 and Figure 3.

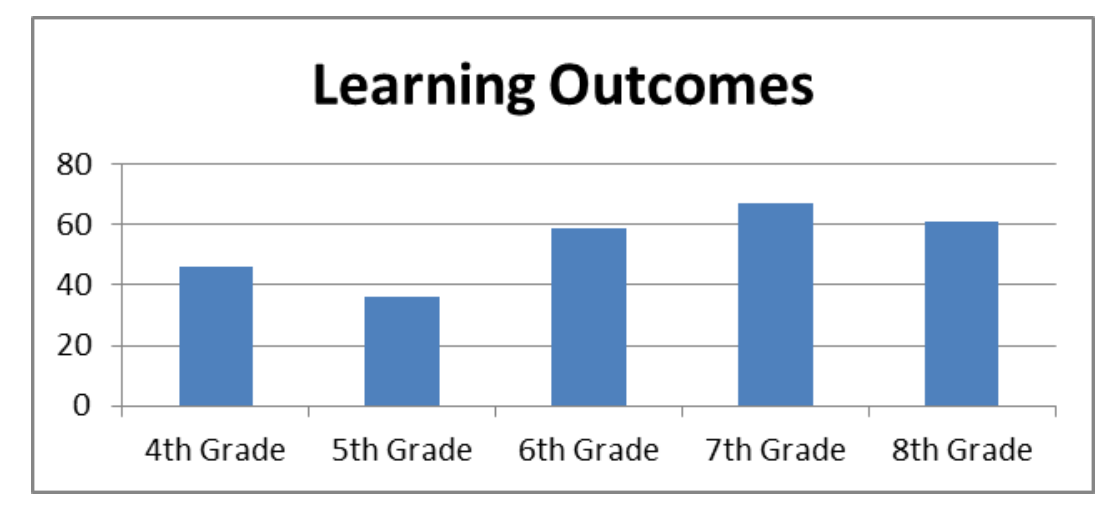

Figure 1. Numbers of the Learning Outcomes 
Gulbin Ozkan \& Unsal Umdu Topsakal, Analysis of Turkish Science Education Curricula's...

As seen in Figure 1, the most science learning outputs are at the seventh-grade level $(n=67)$ and the least science learning outputs are at the fifth grade $(n=36)$ level. As the grade level increases, the number of science learning outcomes does not increase regularly.

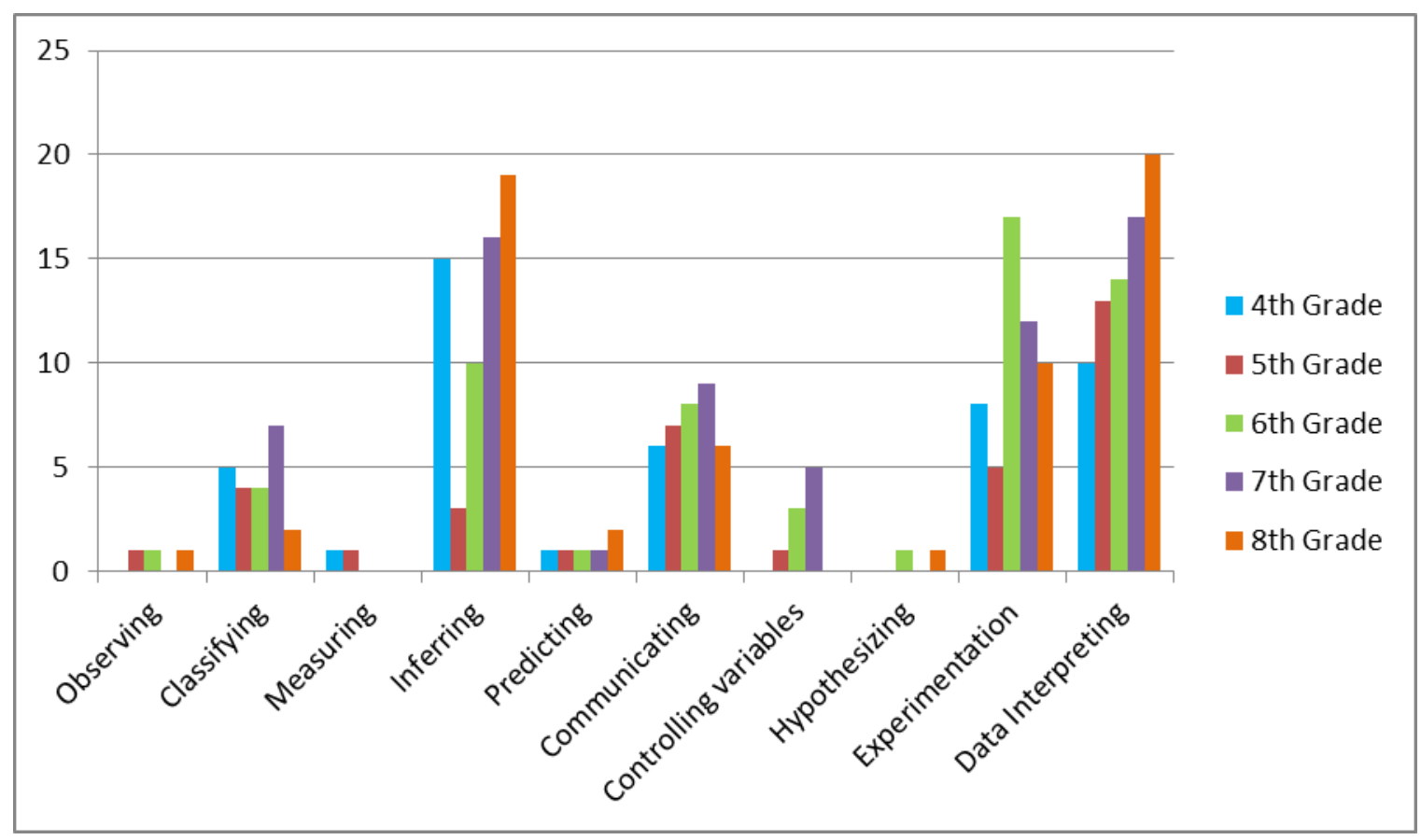

Figure 2. Analysis of learning outcomes according to dimensions of the science process skills

Figure 2 shows which science process skills represent science learning outcomes by grade levels. Considering the dimensions of science process skills, it appears that there is no learning outcome in the "observing" dimension at the fourth and seventh-grade levels, the "measuring" dimension at the sixth, seventh and eighth-grade levels, the "controlling variables" dimension at the fourth and the seventh-grade levels, the "hypothesizing" dimension at the fourth, fifth and seventh grade levels. It was found that the highest frequency was at the eighth-grade level, that is "data interpreting".

In general, the least common science process skills are "measuring" and "hypothesizing" dimensions, while the most common are "data interpreting" and "inferring" dimensions. As the grade level increases, it can be seen that more learning outcomes represent higher-level skills. This increase is most evident in the "data interpreting" dimension.

The frequencies of observing, classifying, measuring, inferring, predicting, and communicating skills were summed for each grade level, and basic process skills frequencies were determined. The frequencies of controlling variables, hypothesizing, experimentation, and data interpreting dimensions were summed for each grade level and integrated science process skills frequencies were obtained. The distribution of basic and integrated science process skills by the level of representation of learning outcomes is presented in Figure 3. 


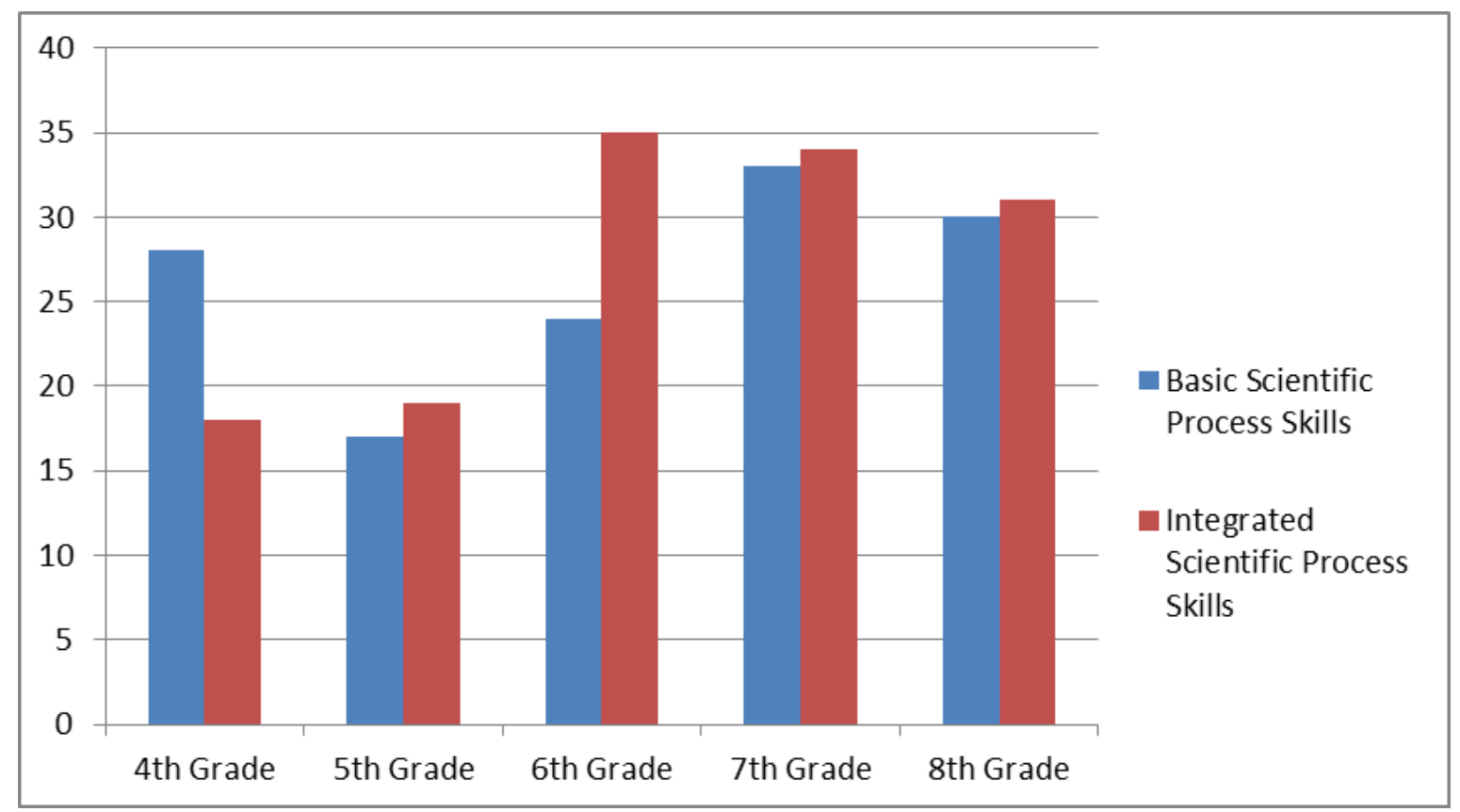

Figure 3. Distribution of science process skills by grade levels

As seen in Figure 3, the number of basic science process skills of the fourth-grade level learning outcomes is higher than the number of integrated science process skills, but the number of integrated science process skills is high in learning outcomes at all other grade levels. On the other hand, as the grade level increases, integrated process skills did not increase numerically in learning outcomes. The number of learning outcomes within the scope of integrated science process skills is 18 in the fourth grade, 19 in the fifth grade, 35 in the sixth grade, 34 in the seventh grade, and 31 in the eighth grade.

\section{DISCUSSION}

In this study, the learning outcomes of the 2018 science education curricula in Turkey were analyzed according to science process skills. The highest science learning outcomes are at the seventh-grade level and the least science learning outputs are at the fifth-grade level. As the grade level increases, the number of science learning outcomes does not increase regularly. Considering the dimensions of science process skills, it appears that there is no learning outcome in the "observing" dimension at the fourth and the seventh-grade levels. The fact that the frequency is zero in this dimension does not mean that no learning outcomes contain observations. Since some learning outcomes that include observation are within the scope of higher-level science process skills, the frequency of this dimension is low. It can be concluded that all class-level frequencies in "classifying" dimension are almost close to each other. At the seventh-grade level, it appears that there was a slightly higher frequency of learning outcomes. While there is a learning outcome in the "measuring" dimension at the fourth and the fifth-grade levels, this dimension is not represented at the other grade levels. "Inferring" is the dimension of learning outcome that is the most represented among all grade levels in basic science process 
Gulbin Ozkan \& Unsal Umdu Topsakal, Analysis of Turkish Science Education Curricula's...

skills. The fact that the learning outcomes that will enable the students to make inferences in the science curricula are high is interpreted as a positive situation. Meanwhile, in the "predicting" dimension, it is concluded that there are almost the same and few learning outcomes at all grade levels. The number of learning outcomes in this dimension is considered to be insufficient for all grade levels. The number of "communicating" dimension of learning outcomes is sufficient for all grade levels. However, there is no learning outcome in the "Controlling variables" dimension at the fourth and eighth-grade levels. Although this situation is considered to be normal at the fourth-grade level, it is thought that there should be a learning outcome for this integrated scientific process skill at the eighth-grade level. In the "hypothesizing" dimension, no learning outcomes were found at the fourth, the fifth, and the seventh-grade levels, and there was only one learning outcome at the sixth and eighth-grade levels. It is thought that the number of learning outcomes of this integrated level science process skills should be increased, especially at upper grade levels. The most learning outcomes in the "experimentation" dimension are found at the sixth-grade level. The number of learning outcomes at the other grade levels seem sufficient. Looking at the "Data interpreting" dimension, it can be seen that the number of learning outcomes increases as the grade level increases.

The number of basic science process skills of the fourth-grade level learning outcomes is higher than the number of integrated science process skills. However, the number of integrated science process skills is high in learning outcomes at all other grade levels. When the distribution of basic and integrated science process skills to classes is taken into account, it can be considered that the distribution is appropriate. Starting from the fifth-grade level, the number of integrated science process skills is higher than the number of basic science process skills. The high level of knowledge of the results in the curricula amplifies the effectiveness of teaching and improves students' high-level learning. To increase the effectiveness of the learning outcomes in curricula, teaching should be done at or above the acquisition dimension (Anderson \& Krathwohl, 2001).

A similar study was conducted by Kilıç, Haymana, and Bozyllmaz (2008). In the study, 2004 science programs were examined. The analysis results of science process skills in learning outcomes show that in all classes, basic science process skills are more emphasized than integrated science process skills. In 2018 science programs, it was seen that while the basic process skills were higher only at the fourth-grade level, the integrated science process skills were higher from the fifth-grade level.

Basic science process skills are critical because they form the foundation of science process skills, and are the skills used even in the smallest systematic study. However, when the basic science process skills are examined, they are not the skills that will lead students to 
comprehensive science practices (Kllıç, Haymana \& Bozyllmaz, 2008). Martin, Sexton \& Gerlovich (2002) state that combined process skills can be developed in upper classes starting from the fourth grade of primary school.

\section{CONCLUSION}

Examining the learning outcomes of curricula is important since they serve as guidelines in designing future programs. In this study, the curricula used in Turkey were examined according to the science process skills. Similarly, other countries will do the same and determine the quality of learning outcomes, and will contribute to curriculum development studies on an international level. It is important to determine which skills the learning outcomes give to the students because these programs will guide teachers. It is a dynamic process that progresses within the development process through program development, continuous trial and research. With such studies, it is thought that it will guide program developers in their next development studies. The science process skills learning outcomes of the Science Education Curricula should be reviewed and the learning outcomes of the higher-level skills should be transferred to higher classes if necessary. Science teaching goals and objectives should be rearranged in a way that can be realized by taking into account the developmental characteristics of students and the developments in science and teaching in the world. Teachers play the most important role in the success of the program. The teacher who takes an active role in the development of the program to be implemented and knows the program and its elements closely will contribute greatly to the success of the program. Therefore, teachers play an active role in the program evaluation and development.

This study is limited to the education program in Turkey. In the future, studies that compare the programs of other countries in the international sense can be conducted. In addition, in this study, the science curriculum was examined in terms of science process skills. In new studies, it is recommended to examine the curriculum in terms of other variables.

\section{REFERENCES}

Aktamış, H. \& Ergin, E. (2007). Bilimsel süreç ile bilimsel yaratıcılık arasındaki ilişkinin belirlenmesi. H. Ü. Eğitim Fakültesi Dergisi, [Determining the relationship between scientific process and scientific creativity. H. U. Journal of the Faculty of Education] 33 (1), 11-23.

Anderson, L.W. \& Krathwohl, D.R. (2001). Taxonomy for learning, teaching and assessing: A revision of bloom's taxonomy of educational objectives. Needham Heights, MA: Allyn \& Bacon.

Bağcı-Kılıç, G. (2003). Üçüncü uluslararası matematik ve fen araştırması (TIMSS): Fen öğretimi, bilimsel araştırma ve bilimin doğası. İlköğretim Online, [Third international mathematics and science research (TIMSS): science teaching, scientific research and the nature of 
Gulbin Ozkan \& Unsal Umdu Topsakal, Analysis of Turkish Science Education Curricula's...

science. Elementary Education Online], 2(1), 42-51.

Bayrak, B., \& Erden, M. A. (2007). Fen Bilgisi Öğretim Programının Değerlendirilmesi. Kastamonu Eğitim Dergisi, [Evaluation of Science Curriculum. Kastamonu Journal of Education] 15(1), 137-54.

Çepni, S., Ayas, A., Johnson, D. \& Turgut, F. (1997). Fizik öğretimi. Ankara: YÖK/Dünya Bankası Milli Eğitimi Geliştirme Projesi. [Physics teaching. Ankara: YÖK/World Bank National Education Development Project]

Chan, M. T. (2002). The teaching of science process skills: primary teachers' self-perception. Asia-Pacific Journal of Teacher Education \& Development, 5 (1), 91-111.

Chiappetta, E., \& Koballa, T. (2002). Science Instruction in the Middle and Secondary Schools (5th ed). Upper Saddle River, NJ: Merrill Prentice Hall.

Collins, A. (1989). Elementary school science curricula that have potential to promote scientific literacy (and how to recognize one when you see one). In A Champagne B. Lowitts ve B. Caliger (Eds), Scientific Literacy, Washington DC: American Association For Advancement of Science.

Crowe, A., Dirks, C., \& Wenderoth, M.P. (2008). Biology in bloom: Implementing Bloom's taxonomy to enhance student learning in Biology. CBE-Life Sciences Education, 7(4), 368-381.

Ergül, R., Şımşeklı, Y., Çaliş, S., Özdılek, Z., Göçmençelebı, Ş., \& Şanli, M. (2011). The effects of inquiry-based science teaching on elementary school students' science process skills and science attitudes. Bulgarian Journal of Science \& Education Policy, 5(1), 48-68.

Germann, J. P. (1994). Testing a model of science process skills acquisition: an interaction with parents' education, preferred language, gender, science attitude, cognitive development, academic ability, and biology knowledge. Journal of Research in Science Teaching, 31 (7), 749-783.

Handayani, S. L. (2021). Comparison of basic science process skills for students on electrical materials with the Rasch model analysis. Jurnal Penelitian \& Pengembangan Pendidikan Fisika, 7(1), 73-82.

Howe, A. C. (2002). Engaging children in science (Third edition). USA: Merrill Prentice Hall.

Ilma, S., Al-Muhdhar, M. H. I., Rohman, F., \& Saptasari, M. (2020). The correlation between science process skills and biology cognitive learning outcome of senior high school students. JPBI (Jurnal Pendidikan Biologi Indonesia), 6(1), 55-64. 
Ivanitskaya, L., Clark, D., Montgomery, G., \& Primeau, R. (2002). Interdisciplinary learning: Process and outcomes. Innovative Higher Education, 27(2), 95-111.

Karamustafaoğlu, S. (2011). Improving the science process skills ability of science student teachers using I diagrams. Eurasian Journal of Physics and Chemistry Education, $3(1), \quad 26-38$.

Kaymakci, G., \& Can, S. (2021). Investigation of the effects of some variables on middle school students' problem-solving skills, science process skills and learning styles. Educational Policy Analysis and Strategic Research, 16(1), 394-426.

Kıııç, G. B., Haymana, F., \& Bozyılmaz, B. (2010). Illköğretim fen ve teknoloji dersi öğretim programı'nın bilim okuryazarlığı ve bilimsel süreç becerileri açısından analizi. Eğitim ve Bilim, [Analysis of primary school science and technology curriculum in terms of science literacy and scientific process skillsscience process skills. Education and Science, 33(150), 52-63.

Kim, S. Y., \& Alghamdi, A. K. H. (2019). Female secondary students' and their teachers' perceptions of science learning environments within the context of science education reform in Saudi Arabia. International Journal of Science and Mathematics Education, 17(8), 1475-1496.

Martin, D. J. (2012). Elementary science methods: constructivist approach (6. edition). USA: Cengage Learning.

Martin, R., Sexton, C., \& Gerlovich, J. (2002). Teaching Science for all Children. Boston: Allyn and Bacon.

McCroskey, J. C., \& Richmond, V. P. (1987). Willingness to communicate and interpersonal communication. In J. C. McCroskey \& J. A. Daly (Eds.), Personality and interpersonal communication (129-156). Beverly Hills, CA: Sage.

Millar, R. (1994). What is scientific method and can it be taught? In R. Levinson (Ed.), Teaching sceince. London: Open University Press.

Ministry of National Education (MONE), (2018). Science Curricula. Ankara: Board of Education and Training.

Osman, K. (2012). Primary science: Knowing about the world through science process skills. Asian Social Science, 8(12), 1-7.

Ostlund, K. L. (1992). Science process skills: assessing hands-on student performance. New York: Addison-Wesley. 
Gulbin Ozkan \& Unsal Umdu Topsakal, Analysis of Turkish Science Education Curricula's...

Peng, J. E. (2011). Towards an ecological understanding of willingness to communicate in EFL classrooms in China. System, 40, 203-213. http://dx.doi.org/10.1016/j.system.2012.02.002

Rubin, R.L. ve Norman, J.T. (1992). Systematic modeling versus learning cycle: comparative effects on integrated science process skills achievement. Journal of Research in Science Teaching, 29(1), 715-727.

Şahin- Pekmez, E. (2000). Procedural understanding: Teachers perception of conceptual basis of pratical work. PhD Thesis, University of Durham, Durham.

Tanık, N. \& Saraçoğlu, S. (2011). Examination of the written questions of science and technology lesson according to the renewed bloom taxonomy. TÜBAV Journal of Science, 4(4), 235246.

Ural, E., \& Gençoğlan, D. M. (2019). The effect of argumentation-based science teaching approach on 8th graders' learning in the subject of acids-bases, their attitudes towards science class and scientific process skills science process skills. Interdisciplinary Journal of Environmental and Science Education, 16(1), 1-15.

Waltz, M. J., Moberly, H. K., \& Carrigan, E. (2020). Identifying information literacy skills and behaviors in the curricular competencies of the professional health curricula. Journal of the Medical Library Association, 108 (3) 463-479.

Yildirim, M., Acarli, D. S., \& Kasap, M. Y. (2020). Investigation of in-service and pre-service science teachers' perceptions of scientific process skills science process skills. Asian Journal of University Education, 16(2), 104-115.

Yüksel, S. (2007). New developments and classifications in taxonomy. Turkish Journal of Educational Sciences, 5(3), 479-509.

Zeidan, A. H., \& Jayosi, M. R. (2015). Science Process Skills and Attitudes toward Science among Palestinian Secondary School Students. World journal of Education, 5(1), 13-24.

Zorluoglu, S. L., \& Kizilaslan, A. (2019). Analysis of 10th Chemistry Curriculum According to Revised Bloom Taxonomy. Journal of Education and e-Learning Research, 6(2), 88-95.

Zorluoglu, S. L., Bagriyanik, K. E., \& Sahintürk, A. (2019). Analyze of the Science and Technology Course TEOG Questions Based on the Revised Bloom Taxonomy and Their Relation between the Learning Outcomes of the Curriculum. International Journal of Progressive Education, 15(2), 104-117. 